Available online at GSC Online Press Directory

GSC Biological and Pharmaceutical Sciences

e-ISSN: 2581-3250, CODEN (USA): GBPSC2

Journal homepage: https://www.gsconlinepress.com/journals/gscbps

(RESEARCH ARTICLE)

\title{
Antibiotic susceptibility pattern of isolates from urine of students in Benue State Polytechnic, Ugbokolo, Nigeria
}

\author{
Peter Adikwu 1, ${ }^{*}$, Mlumum E ${ }^{2}$, Oyiwona EG ${ }^{2,3}$, Adejor Johnson ${ }^{2}$ and Ebiega ET 2 \\ ${ }^{1}$ Biological Science Department, Benue State University, Makurdi, Nigeria. \\ 2 Department of Science Laboratory Technology, Benue State Polytechnic, Ugbokolo, Nigeria. \\ ${ }^{3}$ Benue State Ministry of Energy, Science and Technology (Commissioner).
}

Publication history: Received on 23 August 2020; revised on 08 October 2020; accepted on 12 October 2020

Article DOI: https://doi.org/10.30574/gscbps.2020.13.1.0276

\begin{abstract}
Background: Urinary Tract Infections (UTIs) remains one of the most common infectious diseases diagnosed in developing countries. The widespread use of antibiotics against uro-pathogens has led to the emergence of antibiotic resistant species.

Objectives: The study aimed at determining the antibiotic susceptibility pattern of isolates from urine of students in Benue State Polytechnic, Ugbokolo, Nigeria.

Materials and methods: Three hundred and twenty seven (327) midstream urine samples from 137 (41.9\%) males and 190 (58.1\%) females were collected from students in hostels of Benue State Polytechnic, Ugbokolo. The urine samples were inoculated into the dried surfaces of Blood agar, MacConkey agar, Eosine Methylene Blue agar and Cysteine Lactose Electrolyte-deficient agar using a calibrated loop. The inoculated plates were aerobically incubated at $37 \mathrm{oC}$ for $24 \mathrm{~h}$. Colonies were sub-cultured repeatedly to obtain a pure culture. E.coli (ATCC 25922) and S. aureus (ATCC 25923) standard reference strain were used as control. The isolates were identified using cultural and biochemical characteristics such as Gram stain, Triple Sugar Iron agar test, methyl red, Voges-Proskauer, citrate utilization, catalase, oxidase, urease and coaulase test. The identified species were then exposed to selected antibiotics to test for their susceptibility.
\end{abstract}

Results: A high prevalence of $15.9 \%(n=327)$ was recorded in the study. Significant differences $(\mathrm{P}<0.05)$ were observed in the age, sex and number of isolates. Isolation rate showed female $(63.5 \%, \mathrm{n}=33)$ preponderance over male $(36.5 \%$, $\mathrm{n}=19)$. Isolation rate was highest in students aged $22-26(44.2 \%, \mathrm{n}=23)$. E. coli was the most frequently isolated organism. The Gram negative bacterial isolates showed the highest level of resistance to amoxicillin (92.3\%, $\mathrm{n}=36)$ and SXT $(92.3 \%, n=36)$ while the Gram positive exhibited the highest level of resistance to SXT $(87.5 \%, n=7)$. All the isolates were however susceptible to imipenen and gentamycin.

Conclusion: The high prevalence showed by this study suggests the existence of a public health concern among the students. The fact that most of these isolates are resistant to one or more of the commonly used antibiotics calls for con

Keywords: Prevalence; Infection; Antibiotic resistance; Diagnose; Susceptibility.

\footnotetext{
${ }^{*}$ Corresponding author: Peter Adikwu

Biological Science Department, Benue State University, Makurdi, Nigeria.

Copyright (@ 2020 Author(s) retain the copyright of this article. This article is published under the terms of the Creative Commons Attribution Liscense 4.0.
} 


\section{Introduction}

Urinary tract infections (UTIs) are the most common infections in humans that can affect any part of the urinary system including kidneys, ureters, bladder or urethra [1]. It is estimated that approximately 150 million cases occur globally every year [2]. UTIs remain one of the most common infectious diseases diagnosed in outpatients [3]. It is most often caused by bacteria but may also be caused by fungal and viruses [4] [3]. Dadi et al. [5] opined that Gram-negative bacteria causes $90 \%$ of UTI cases while Gram-positive cause only $10 \%$ of the cases.

Numerous risk factors can increase the likelihood of developing a UTI, including female gender, sexual intercourse, poor personal hygiene, diabetes, obesity, vaginal infections and heavy use of antibiotics [6] [1]. Amdekar et al., [4] reported that the incidence is quite high among women due to the anatomy and physiology of their reproductive organ. The relative frequency of uro-pathogens varies depending on age, sex, catheterization and previous exposure of antimicrobials [3]. The leading pathogens of UTIs are Escherichia coli, Klebsiella pneumoniae, Proteus mirabilis, Pseudomonas aeruginosa, Staphylococcus aureus, Enterococcus faecalis and Candida spp. [2] [7] [8].

The emergence of antibiotic resistance in the management of UTIs is a serious public health issue; particularly in the developing countries characterize by high level of poverty, illiteracy and poor hygienic practices [9]. There are also high cases of drugs of questionable quality in circulation. The easy availability in the community without prescription makes the drug subject to abuse [10]. Knowledge of the local bacterial etiology and susceptibility patterns will be a useful guide in the effective and timely treatment of UTIs. Antibiotic therapy in the mainstay is the treatment of UTIs but unfortunately the emergence of multi-drug resistant strains of the causative organisms has become a major challenge of epidemiological importance [4] [11] [10]. The aim of the study was to determine the prevalence of uro-pathogens and in vitro susceptibility pattern to commonly used antibiotics among patients in health centres within Ugbokolo, Benue State.

\section{Material and methods}

\subsection{Specimen collection}

$10 \mathrm{ml}$ of midstream clean urine specimens were collected in sterile containers from 327 students in different hostels of Benue State Polytechnic and taken to the microbiology laboratory of the institution for analysis and culturing on appropriate bacteriological media as suggested by Ochei and Kolhatker, [12] [8].

\subsection{Bacteria Culture and Identification}

$0.01 \mathrm{~mL}$ of mid-stream urine (MSU) specimen were inoculated onto the dried surfaces of Blood agar, MacConkey agar, Eosine methylene blue agar (EMBA) and Cystine lactose electrolyte-deficient agar (CLED) using a calibrated loop. The inoculated plates were aerobically incubated at $37^{\circ} \mathrm{C}$ for $24 \mathrm{~h}$. The incubation period was extended for a further $24 \mathrm{~h}$ in some cases. Colonies were sub-cultured repeatedly to obtain a pure culture. S. aureus (ATCC 25923) and E. coli (ATCC 25922) standard reference strains were used as control for culture media. The sterility of culture media was checked in line with laboratory protocol. Bacterial identification was based on standard culture and biochemical characteristics of isolates such as Gram stain, triple sugar-iron agar, methyl-red, Voges-Proskauer, citrate utilization, catalase production, oxisase reaction, urease, coagulase and motility tests as suggested by Cheesbrough [13], Ochei and Kolhatker [12] and Arora and Arora [14].

\subsection{Antibiotic Susceptibility Test}

The isolates were subjected to antimicrobial susceptibility test using the standard Kirby-Bauer disc diffusion method as described by Arora and Arora [14]. Results were interpreted using the criteria of the Clinical Laboratory Standards Institute [15]. Overnight cultures of the isolates were inoculated into a test tube containing $5 \mathrm{ml}$ of phosphate buffered saline (PBS). The turbidity of each inoculum was adjusted to $0.5 \mathrm{McFarland}$ standard prepared by mixing given amounts of Barium chloride and sulphuric acid.

The standardized culture was evenly spread over the entire surface of Mueller-Hinton agar (Oxoid, CM 0337) plates using sterile swab stick. Sterile forceps was used to carefully pick and gently place the antibiotic discs of known concentrations on the dried but inoculated surface of the Mueller-Hinton agar plates. The discs were gently pressed onto the medium surface with a sterilized forceps to ensure firm contact. The plates were incubated at $37^{\circ} \mathrm{C}$ for $24 \mathrm{~h}$. 
The antibiotic impregnated discs (Oxoid Ltd) used were Amoxicillin/clavulanic (30 $\mu \mathrm{g})$, ceftazidime (30 $\mu \mathrm{g})$, ceftriaxone $(30 \mu \mathrm{g})$, amoxicillin $(10 \mu \mathrm{g})$, sulphamethoxazole/trimethoprim $(25 \mu \mathrm{g})$, chloramphenicol $(30 \mu \mathrm{g})$, ciprofloxacin $(5 \mu \mathrm{g})$, azithromycin $(15 \mu \mathrm{g})$, gentamycin $(30 \mu \mathrm{g})$ and imipenen $(10 \mu \mathrm{g})$.

Diameters of zones of inhibition (if any) around the antibiotic disc were measured to the nearest millimetre using a ruler and results reported as sensitive, intermediate or resistant for each antibiotics used.

\subsection{Data Analysis}

Statistical analyses were done using Statistical Package for Social Sciences (SPSS) version 17 (2008). Pearson's chisquare test was used to determine associations between variables at 95\% confidence level. A p value less than or equal to 0.05 was considered to be indicative of a statistically significant relationship. Analysis of variance (ANOVA) was used to determine associations between variables (age, sex, locations, seasonal variation and rate of multi-drug resistance).

\section{Results and discussion}

Table 1 Prevalence of UTIs with Respect to Age.

\begin{tabular}{|c|c|c|}
\hline Age (Years) & Positive (\%) & Negative (\%) \\
\hline $17-21$ & 7 (13.5) & $33(12.0)$ \\
\hline $22-26$ & $23(44.2)$ & $124(45.1)$ \\
\hline $27-31$ & $16(30.8)$ & $92(33.5)$ \\
\hline $32-36$ & $4(7.7)$ & $16(5.8)$ \\
\hline$\geq 37$ & $2(3.8)$ & $10(3.6)$ \\
\hline Total & $52(100)$ & $275(100)$ \\
\hline
\end{tabular}

Table 2 Prevalence of UTIs with Respect to Sex

\begin{tabular}{l|ll|}
\hline \multicolumn{1}{l}{ Sex } & \multicolumn{1}{l}{ Positive (\%) } & \multicolumn{1}{l}{ Negative (\%) } \\
\hline \multicolumn{1}{l}{ Male } & $19(36.5)$ & $118(42.9)$ \\
\hline Female & $33(63.5)$ & $157(57.1)$ \\
\hline Total & $52(100)$ & $275(100)$ \\
\hline \multicolumn{3}{c}{$\chi=10.371, \mathrm{df}=1, \mathrm{P}<0.0$} \\
\hline
\end{tabular}

Table 3 Frequency of Bacterial Isolates

\begin{tabular}{l|l|}
\hline Bacterial Isolates & Frequency (\%) \\
\hline Escherichia coli & $22(46.8)$ \\
\hline Klebsiella pneumoniae & $14(29.7)$ \\
\hline Staphylococcus aureus & $6(12.8)$ \\
\hline Proteus mirabilis & $3(6.4)$ \\
\hline Streptococcus species & $2(4.3)$ \\
\hline Total & $47(100)$ \\
\hline
\end{tabular}


Table 4 Antibiotic susceptibility pattern of gram-negative bacteria isolates among students of Benue State Polytechnic, Ugbokolo.

\begin{tabular}{|c|c|c|c|c|c|c|c|c|c|c|c|}
\hline $\begin{array}{l}\text { Bact. } \\
\text { isolates }\end{array}$ & $\mathbf{n}$ & Pattern & CIP & AML & CRO & CAZ & SXT & AMC & C & GN & IMP \\
\hline \multirow[t]{3}{*}{ E. coli } & 22 & $\mathrm{~S}$ & $18(81.8)$ & $0(0)$ & $16(72.7)$ & $15(68.2)$ & $1(4.5)$ & $20(90.0$ & $2(9.1)$ & $20(90.0$ & $22(100)$ \\
\hline & & I & $1(4.5)$ & $1(4.5)$ & $4(18.2)$ & $6(27.3)$ & $0(0)$ & $0(0)$ & $1(4.5)$ & $2(9.1)$ & $0(0)$ \\
\hline & & $\mathrm{R}$ & $3(13.6)$ & $21(95.5)$ & $2(9.1)$ & $1(4.5)$ & $21(95.5)$ & $2(9.1)$ & $19(86.4)$ & $0(0)$ & $0(0)$ \\
\hline $\begin{array}{l}\text { K. } \\
\text { pneumoniae }\end{array}$ & 14 & $\begin{array}{l}\mathrm{S} \\
\mathrm{I} \\
\mathrm{R}\end{array}$ & $\begin{array}{l}10(71.4 \\
1(7.1) \\
3(21.4)\end{array}$ & $\begin{array}{l}0(0) \\
1(7.1) \\
13(92.9)\end{array}$ & $\begin{array}{l}8(57.1) \\
0(0) \\
6(42.9)\end{array}$ & $\begin{array}{l}0(0) \\
3(21.4) \\
11(78.6)\end{array}$ & $\begin{array}{l}0(0) \\
0(0) \\
14(100)\end{array}$ & $\begin{array}{l}11(78.6 \\
1(7.1) \\
2(14.2)\end{array}$ & $\begin{array}{l}0(0) \\
1(7.1) \\
13(92.9)\end{array}$ & $\begin{array}{l}14(100) \\
0(0) \\
0(0)\end{array}$ & $\begin{array}{l}14(100) \\
0(0) \\
0(0)\end{array}$ \\
\hline \multirow[t]{3}{*}{ P. mirabilis } & 3 & $\mathrm{~S}$ & $2(66.7)$ & $0(0)$ & $2(66.7)$ & $1(33.3)$ & $0(0)$ & $2(66.7)$ & $0(0)$ & $0(0)$ & $3(100)$ \\
\hline & & I & $1(33.3)$ & $1(33.3)$ & $0(0)$ & $1(33.3)$ & $2(66.7)$ & $0(0)$ & $2(66.7)$ & $0(0)$ & $0(0)$ \\
\hline & & $\mathrm{R}$ & $0(0)$ & $2(66.7)$ & $1(33.3)$ & $1(33.3)$ & $1(33.3)$ & $1(33.3)$ & $1(33.3)$ & $3(100)$ & $0(0)$ \\
\hline Total & 39 & $\begin{array}{l}\mathrm{S} \\
\mathrm{I} \\
\mathrm{R}\end{array}$ & $\begin{array}{l}30(76.9 \\
3(7.7) \\
6(15.4)\end{array}$ & $\begin{array}{l}0(0) \\
3(7.7) \\
36(92.3)\end{array}$ & $\begin{array}{l}26(66.7) \\
4(10.3) \\
9(23.0)\end{array}$ & $\begin{array}{l}16(41.0) \\
10(25.6) \\
13(33.3)\end{array}$ & $\begin{array}{l}1(2.6) \\
2(5.1) \\
36(92.3)\end{array}$ & $\begin{array}{l}33(84.6 \\
1(2.6) \\
5(12.8)\end{array}$ & $\begin{array}{l}2(5.1) \\
4(10.3) \\
33(84.6)\end{array}$ & $\begin{array}{l}34(87.2 \\
2(5.1) \\
3(7.7)\end{array}$ & $\begin{array}{l}39(100) \\
0(0) \\
0(0)\end{array}$ \\
\hline
\end{tabular}

Table 5 Antibiotic susceptibility pattern of gram-positive bacteria isolates among students of Benue State Polytechnic, Ugbokolo.

\begin{tabular}{|c|c|c|c|c|c|c|c|c|c|c|c|}
\hline $\begin{array}{l}\text { Bact. } \\
\text { isolates }\end{array}$ & $\mathbf{n}$ & Pattern & CIP & AML & CRO & CAZ & SXT & AMC & C & GN & IMP \\
\hline \multirow[t]{3}{*}{ S. aureus } & 6 & $\mathrm{~S}$ & $4(66.7)$ & $0(0)$ & $0(0)$ & $4(66.7)$ & $1(16.7)$ & $3(50.0)$ & $2(33.3)$ & $4(66.7)$ & $6(100)$ \\
\hline & & I & $0(0)$ & $1(16.7)$ & $2(33.3)$ & $0(0)$ & $0(0)$ & $1(16.7)$ & 1(16.7) & $2(33.3)$ & $0(0)$ \\
\hline & & $\mathrm{R}$ & $2(33.3)$ & $5(83.3)$ & $4(66.7)$ & $2(33.3)$ & $5(83.3)$ & $2(33.3)$ & $3(50.0)$ & $0(0)$ & $0(0)$ \\
\hline \multirow[t]{3}{*}{ S. spp } & 2 & $\mathrm{~S}$ & $1(50.0)$ & $0(0)$ & $1(50.0)$ & $0(0)$ & $0(0)$ & $1(50.0)$ & $0(0)$ & $1(50.0)$ & $2(100)$ \\
\hline & & I & $0(0)$ & $1(50.0)$ & $1(50.0)$ & $0(0)$ & $0(0)$ & $1(50.0)$ & $0(0)$ & $1(50.0)$ & $0(0)$ \\
\hline & & $\mathrm{R}$ & $1(50.0)$ & $1(50.0)$ & 00 & $2(100)$ & $2(100)$ & $0(0)$ & $2(100)$ & $0(0)$ & $0(0)$ \\
\hline \multirow[t]{3}{*}{ Total } & 8 & $\mathrm{~S}$ & $5(62.5)$ & $0(0)$ & $1(12.5)$ & $4(50.0)$ & $1(12.5)$ & $4(50.0)$ & $2(25.0)$ & $5(62.5)$ & $8(100)$ \\
\hline & & I & $0(0)$ & $2(25.0)$ & $3(37.5)$ & $0(0)$ & $0(0)$ & $2(25.0)$ & $1(12.5)$ & $3(37.5)$ & $0(0)$ \\
\hline & & $\mathrm{R}$ & $3(37.5)$ & $6(75.0)$ & $4(50.0)$ & $4(50.0)$ & $7(87.5)$ & $2(25.0)$ & $5(62.5)$ & $0(0)$ & $0(0)$ \\
\hline
\end{tabular}




\section{Discussion}

The prevalence and antibiotic susceptibility pattern of uropathogens from urine of students of Benue State Polytechnic, Ugbokolo was determined. Results of the study showed the overall prevalence of isolates to be $15.9 \%$ ( $n=52$ ). This is consistent with the findings of Ehinmidu, [16], Marwan et al. [1] and Ahmed et al. [8]. The high prevalence of UTIs in the present study suggests the existence of a significant public health hazard in the study area.

Students within the age range of 22-26 (44.2\%, $\mathrm{n}=23)$ had the highest prevalence of isolates. This agrees with the findings of Dadi et al. [5]. The high prevalence within the age group could be attributable to high sexual activity within this age group as reported by Singh et al. [17]. The implication of this finding is that the education of the youth who form the major workforce of the population, and the farming activities which is the main source of economic livelihood will be affected.

Isolation rate showed female $(63.5 \%, \mathrm{n}=33)$ preponderance over male $(36.5 \%, \mathrm{n}=19)$ students. This agrees with the findings of Singh et al. [17], Dadi et al. [5]. Other supporting earlier studies are those of Ibssa and Solomon, [9] and Wubalem and Alemayehu, [3].This could be due to the anatomical differences of urogenital organs between the two sexes. Gupta et al. [18] and Wubalem and Alemayehu, [3] opined that poor hygiene practice may result in direct faecal contamination of urinary tract from the anus in females, consequently providing easier access to the pathogens overgrowth and ascent to the bladder.

Among the isolates, Gram negative bacteria constitute $82.9 \%(\mathrm{n}=39)$ while Gram positive bacteria constitute $17.1 \%$ $(\mathrm{n}=8)$. The higher prevalence of Gram negative bacteria in this study agrees with that reported by Mizarzi, [19]; and Wubalem and Alemayehu, [3]. The prevalence of E. coli $(46.8 \%, \mathrm{n}=22)$ in this study corroborates that of Ehinmidu, [16] and Wubalem and Alemayehu, [3] in Zaria, Nigeria and Ethiopia respectively. It is however higher than that of Ullah et al. [20]; and Beyene and Tsegaye, [21]. The prevalence of $S$. aureus $(12.8 \%, \mathrm{n}=6)$ in this study is consistent with the findings of Ibssa and Solomon, [9] and Wubalem and Alemayehu, [3]. The other isolates ranged between 5 to $10 \%$ which agrees with findings of Mohammad et al. [7], Singh et al. [17] and Dadi et al. [5].

The results of the finding also showed that all the Gram negative isolates were susceptible to imipenen (100\%, $\mathrm{n}=39)$, followed by Gentamicin. They however showed a high level of resistance to Amoxycillin (92.3\%, n=36) and SXT (92.3\%, $\mathrm{n}=36)$. Similarly, the study revealed the most effective antibiotic against the Gram positive isolates to be Imipenen $(100 \%, n=8)$. They however showed a high level of resistance to SXT $(87.5 \%, n=7)$. This agrees with the findings of Harriet and Nandita, [11], Mohammad et al. [7] and Wubalem and Alemayehu, [3].

\section{Conclusion}

The prevalence and antibiotic susceptibility pattern of isolates from urine of students of Benue State Polytechnic, Ugbokolo was determined. The study showed a prevalence of $19.3 \%$ in the studied area. The most frequently isolated organisms are Escherichia coli, Klebsiella pneumoniae, Staphylococcus aureus, Proteus mirabilis and Streptococcus spp. Isolation rate showed female preponderance over male and age range 22-26 recorded the highest. All the isolates were susceptible to Imipenen followed by Gentamycin. They however showed high resistance to amoxicillin and sulponamide/trimetripine.

\section{Compliance with ethical standards}

\section{Acknowledgments}

We acknowledge the staff members of Microbiology Laboratory Unit, Benue State Polytechnic, Ugbokolo for granting us the permission to make use of the laboratory. We are equally indebted to the management and staff of Charis Rhema Research and Diagnostic Laboratories, Makurdi, Benue State, Nigeria for assisting us with susceptibility test kits.

\section{Disclosure of conflict of interest}

There is no conflict of interest between the authors. All authors of the manuscript have read and agreed to its content and are accountable for all aspects of the accuracy and integrity of the manuscript. 


\section{Author's contributions}

A.P., M.E. and E.E.T. designed the study, carried out the bench work and data acquisition for analysis. A.J. did the data analysis and interpretation of results. A.P. did the drafting of the manuscript. Revision of the manuscript for critical intellectual content was done by A.P. and O.G.E. All authors gave final approval of the version to be published.

\section{Statement of informed consent}

Consent form was administered and filled by each participant.

\section{References}

[1] Marwan O, Hassan M, Monzer H, Elie BR. Prevalence and Antibiotic Susceptibility Patterns of Bacteria Causing Urinary Tract Infections in Youssef Hospital Centre: First Report from Akkar Governorate, North Lebanon. International Arabic Journal of Antimicrobial Agents. 2017; 7(1): 2-4.

[2] Flores-Mireles AL, Walker JN, Caparon M, Hultgren SJ. Urinary Tract Infection: Epidemiology, Mechanisms of Infection and Treatment Options. Nature Review Microbiology. 2015; 13(5): 269-284.

[3] Wubalem DS, Alemayehu DG. Prevalence and Antibiotic Susceptibility of Uropathogens from Cases of Urinary Tract Infections (UTI) in Shashemene Referal Hospital, Ethiopia. BMC Infectious Diseases. 2018; 18(1):1-9.

[4] Amdekar S, Singh V, Singh DD. Probiotic Therapy: immunodulating approach toward urinary tract infection. Current Microbiology. 2011; 63(5): 484-490.

[5] Dadi M, Senthilkumar B, Berhanu S. Prevalence, Antimicrobial Susceptibility Pattern of Bacterial Isolates and Associated Factors of Urinary Tract Infections among HIV-Positive patients at Hiwot Fana Specialized University Hospital, Eastern Ethiopia. Canadian Journal of Infectious Diseases and Medical Microbiology. 2019; 20(9): 1-8.

[6] Levison ME, Kaye D. Treatment of Complicated Urinary Tract Infections with Emphasis on Drug-Resistant Gramnegative Uropathogens. Current Infectious Disease Report. 2013; 15(2): 109-115.

[7] Mohammad, A., Soyar, S., Mohammadreza, N., Seyed, S.R.H. and Samaneh, M. Prevalence and Antibiotic Susceptibility Pattern of E. coli Isolated from Urinary Tract Infection in Patients with Renal Failure Disease and Renal Transplant Recipients. Tropical Journal of Pharmaceutical Research. 2015; 14(4): 649-653.

[8] Ahmed AA, Mahmoud AC, Haval HA. Prevalence and Antimicrobial Susceptibility of Bacterial Pathogens Isolated from Urine Specimens Received in Rizgary Hospital- Erbil. Journal of Infection and Public Health. 2019; 12: 330336.

[9] Ibssa and Solomon. Common Bacterial Pathogens and Their Antimicrobial Susceptibility Patterns in Patients with Symptomatic Urinary Tract Infections at Hiwot-Fana and Jugal Hospitals, Harar City, Estern Ethiopia. Galore International Journal of Health Sciences and Research. 2018; 3(2): 8-14.

[10] Adikwu P, Umeh EU, Iheukwumere CC, Ogbonna IO, Awodi PS, Obande GA. Variation in Salmonella typhi Infection Among Local Populations in Southern Benue, Nigeria. International Journal of Enteric Pathogens. 2018; 6(4): 8994.

[11] Harriet U, Nandita D. Mechanisms of Antibiotic resistance in Salmonella typhi. International Journal of Current Microbiology and Applied Science. 2014; 3(12): 461-476.

[12] Ochei J0, Kolhatkar A. Medical Laboratory Science and Practice. Tata McGrew-Hill Publishing Limited New Delhi, New York. 2008; 788-817.

[13] Cheesbrough M. District Laboratory Practice in Tropical Countries: Part 2, 2nd edition. Cambridge: Cambridge University Press, New York, NY, USA. 2006; 105-143.

[14] Arora DR, Arora B. A text book of Microbiology. 3rd Edition, CBS publishers PV Ltd, New Delhi, India. 2011; 352412.

[15] Clinical and Laboratory Standards Institute. M100S-S25, Performance Standards for Antimicrobial Susceptibilty Testing; Twenty-Fifth Informational Supplement, Clinical and Laboratory Standards Institute. Pittsburgh, PA, USA. 2015; 35.

[16] Ehinmidu JO. Antibiotics Susceptibility Patterns of Urine Bacterial Isolates in Zaria, Nigeria. Tropical Journal of Pharmaceutical Research. 2003; 2(2): 223-228. 
[17] Singh RK, Dewasy B, Mallick RL, Kafle TK. Prevalence of Antibiotic Sensitivity Pattern of Uropathogens in Patients of Different Age Groups from Western region of Nepal. International Journal of Medical Research and Health Sciences. 2016; 5(9): 1-7.

[18] Gupta K, Scholes D, Stamm WE. Increasing Prevalence of Antimicrobial Resistance among Uropathogens Causing Acute Uncomplicated Cystis in Women. JAMA. 1999; 281(8): 736-738.

[19] Mizarzi M. Antibiotic Resistance of Isolated Gram Negative Bacteria from Urinary Tract Infections (UTIs) in Isfahan, Jundishapur. Journal of Microbiology. 2013; 6(8): 68-83.

[20] Ullah F, Malik S, Ahmed J. Antibiotic Susceptibilty Pattern and ESBL Prevalence in Nosocomial Escherichia coli from Urinary Tract Infections in Pakinstan. African Journal of Biotechnology. 2009; 8(16): 3921-3926.

[21] Beyene G, Tsegaye W. Bacterial Uropathogens in Urinary Tract Infection and Antibiotic Susceptibility Pattern in Jimma University Specialized Hospital, Southwest Ethiopia. Ethiopian Journal of Health Science. 2011; 21(2): 141-146. 